\title{
Brazilian sedimentary zeolite use in agriculture
}

\author{
Alberto C. de Campos Bernardi ${ }^{\mathrm{A}, \mathrm{E}}$; Patrícia Peronti Anchão Oliviera ${ }^{\mathrm{A}}$; Marisa B. de Melo Monte ${ }^{\mathrm{B}}$; José \\ Carlos Polidoro ; Fernando Souza-Barros ${ }^{\mathrm{D}}$ \\ ${ }^{\text {A} E m b r a p a ~ P e c u a ́ r i a ~ S u d e s t e, ~ C . P .339, ~ C E P: ~ 13560-970, ~ S a ̃ o ~ C a r l o s, ~ S P, ~ B r a z i l, ~ E m a i l ~ a l b e r t o @ c p p s e . e m b r a p a . b r ~}$ \\ ${ }^{\mathrm{B}}$ Centro de Tecnologias Minerais - CETEM, Rio de Janeiro, RJ, Brazil. \\ ${ }^{\mathrm{C}}$ Embrapa Solos, Rio de Janeiro, RJ, Brazil. \\ ${ }^{\mathrm{D}}$ Instituto de Física UFRJ, Rio de Janeiro, RJ, Brazil. \\ ${ }^{\mathrm{E}} \mathrm{CNPQ}$ fellow.
}

\begin{abstract}
Zeolites are hydrated crystalline aluminosilicate minerals of alkaline and alkaline earth metals, structured in rigid three dimension nets, organized by $\mathrm{AlO}_{4}$ and $\mathrm{SiO}_{4}$ tetrahedral and are of natural occurrence. This report describes the characterization and application of the Brazilian zeolitic sedimentary rock as a release fertilizer and soil conditioner. The characterization of the head samples showed that it is composed of the zeolite stilbite intermixed with a smectitic clay mineral, and quartz. A low-cost quartz separation technique was established. Enrichment of concentrated natural zeolite was carried out: zeolite $+\mathrm{KNO}_{3}$, zeolite $+\mathrm{K}_{2} \mathrm{HPO}_{4}$ and zeolite $+\mathrm{H}_{3} \mathrm{PO}_{4}+$ apatite and the concentrated zeolite. These materials were tested with Rangpur lime rootstock and an experiment was also carried out with successive crops grown on the same substrate: lettuce, tomato, rice, and Andropogon grass. The results indicated that N, P and K enriched zeolite was an adequate slow-release source of nutrients to plants. Other green house and field experiments with concentrated zeolite applied with urea showed reduction of losses of ammonia by volatilization and improved in $\mathrm{N}$ use efficiency by maize. Concentrated zeolite also increased water retention and the available water capacity of a sand soil.
\end{abstract}

\section{Key Words}

Stilbite, slow-release fertilizer, $\mathrm{N}$ losses, water retention curve, available water capacity.

\section{Introduction}

The use of minerals for agricultural purposes is becoming widespread (Van Straaten 2006), and zeolitic concentrates have a special niche in this category. Zeolite minerals are crystalline hydrated aluminosilicates of alkali or alkaline-earth metals, structured in three-dimensional rigid crystalline network, formed by the tetrahedral $\mathrm{AlO}_{4}$ and $\mathrm{SiO}_{4}$, which come together to compose a system of canals, cavities and pores (Ming and Mumpton 1989). The worldwide number of identified natural zeolite - about forty -demonstrates both their great variety and the present-day interest on their potential applications in the industry and the agriculture (Ming and Dixon 1987). These minerals have three main properties, which are of great interest for agricultural purposes: high cation exchange capacity, high water holding capacity in the free channels, and high adsorption capacity (Mumpton 1999). Sediment occurrences of this aluminosilicate are known to exist in northern areas of Brazil (Rezende and Angelica 1999).

Zeolites improves the efficiency of nutrient use by increasing the availability of $\mathrm{P}$ from phosphate rock, the utilization of $\mathrm{N}_{-} \mathrm{NH}_{4}{ }^{+}$and $\mathrm{N}_{-} \mathrm{NO}_{3}{ }^{-}$and reduced losses by leaching of exchangeable cations, especially $\mathrm{K}^{+}$ (Barbarick et al. 1990; Allen et al. 1995; Williams and Nelson 1997; Leggo 2000; and Pickering et al. 2002). Zeolites mixed with phosphate rock, can act as controlled delivery system and renewable source of nutrients for plants (Allen et al. 1995; Barbarick et al. 1990). The increased efficiency of N utilization when urea is used together with zeolite was demonstrated by Crespo (1989), Bouzo et al. (1994), Carrion et al. (1994) and He et al. (2002) that achieved increasing of $\mathrm{N}$ use efficiency, $\mathrm{N}$ uptake and dry matter yield and reductions of losses by ammonia volatilization. Zeolites also improves the efficiency of water use by increasing the soil water holding capacity and its availability to plants (Xiubin and Zhanbin 2001; Bernardi et al. 2008). While literature shows that zeolites are useful for increasing nutrient use efficiency in a range of crops, little information exists on the use of stilbite, in agricultural systems especially on acid soils. The objective of this report was to characterize and test the application of Brazilian zeolitic sedimentary rock as a slow release fertilizer and soil conditioner.

\section{Methods}

Zeolite used was collected in the north of the State of Tocantins, Brazil, in the basin of the Parnaiba river (Rezende and Angelica 1999). It had $470 \mathrm{~g} / \mathrm{kg}$ of stilbite. The material was crushed and part of it was 
concentrated, separating contaminants (quartz and iron oxides and hydroxides) from zeolite by means of gravitational concentration, using the Humphrey spiral, resulting in material with $650 \mathrm{~g} / \mathrm{kg}$ of stilbite. The mineral was classified by sieving followed by Tyler-series grain size selection from 295 to $37 \mu \mathrm{m}$. All fractions were analysed by X-Ray diffraction (XRD). Nutrient adsorption and release properties matched those reported for similar commercial zeolitic products (Monte et al. 2009).

A greenhouse experiment was carried out with $3 \mathrm{~kg}$ pots with an inert substrate with an experimental design of randomized block with three replications. Four levels of enriched zeolite were tested: 20, 40, 80 and 160 $\mathrm{g} /$ pot. And four successive crops were obtained on the same substrate of each pot: lettuce, tomato, rice and Andropogon grass. In another experiment Rangpur lime (Citrus limonia Osbeck) rootstocks were cultivated during 93 days in $150 \mathrm{~cm}^{3}$-dibble tubes containing composted organic substrate of cocopeat and vegetal coal (3:1) with zeolite addition. Treatments comprised four types of enrichment of concentrated natural zeolite: only concentrated zeolite $(\mathrm{Z})$, zeolite $+\mathrm{KNO}_{3}(\mathrm{ZNK})$, zeolite $+\mathrm{K}_{2} \mathrm{HPO}_{4}(\mathrm{ZPK})$ and zeolite $+\mathrm{H}_{3} \mathrm{PO}_{4}+$ apatite (ZP) prepared as described by Monte et al. (2009). These treatments were also compared with adequate available nutrient supplied by complete nutrient solution. The N-urea losses were evaluated with collectors for volatized ammonia capture with phosphoric acid solution $(0.5 \mathrm{~N})$, changed every two days to determine the volatilized ammonia, with 11 samples taken in a period of 22 days.

Evaluation of the mineral as a soil conditioner was undertaken with three levels of zeolite 33.3; 66.7 and $100.0 \mathrm{~g} / \mathrm{kg}$ and a control applied to a sand soil. Samples for the soil water retention were collected with stainless steel cylinders. the water retention curve was determined in a Richard's pressure chamber and the equation of soil volumetric water content as a function of matric potential were adjusted with the van Genuchten model. All data were tested for differences among treatments using an analysis of variance. Response function and equations were adjusted as a function of treatments.

\section{Results}

Characterization analyses demonstrate that the zeolitic sediment and quartz are the major components of the head samples. The head sample contained zeolite stilbite mixed with smectitic clay. A characterization with $\mathrm{X}$-Ray diffraction showed the presence of stilbite (ideal formula, $\left.(\mathrm{Na}, \mathrm{K}) \mathrm{Ca}_{2}\left[\mathrm{Al}_{5} \mathrm{Si}_{13} \mathrm{O}_{36}\right] .14 \mathrm{H}_{2} \mathrm{O}\right)$ as one of main mineral components (Figure 1). The slow-release fertilizer effects of zeolite are a result of ionexchange reactions with the zeolite, or through a combination of ion-exchange and mineral-dissolution reactions. Results of the successive crops of lettuce, tomato, rice and andropogon grass carried out on the same substrate of each pot indicated that N, P and K enriched zeolite was an adequate slow-release source of nutrients to plants (Figure 2A). The experiment also demonstrated the enhanced $\mathrm{P}$ availability from phosphate rock when applied in combination with zeolite, $\mathrm{P}$ availability presented a trend of increasing, especially after the second and third crops unlike the soluble P source (Figure 2 B and 2C).

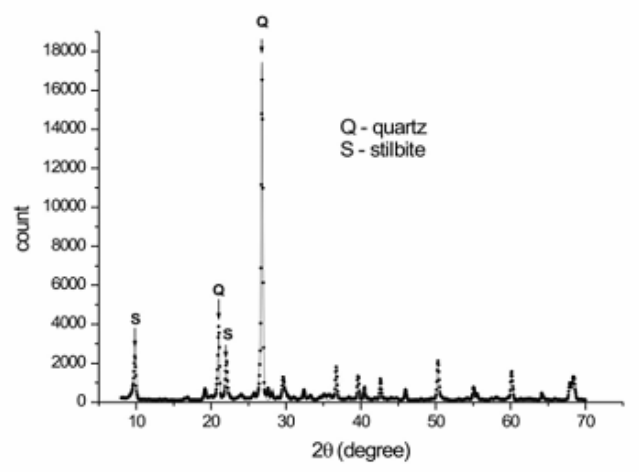

Figure 1. X-Ray diffraction of zeolite stiltbite. Source: Monte et al. (2009).

Figure 3 illustrates that the supply of nutrients through the mineral zeolite enriched with NPK added to the organic substrate was a viable alternative for Rangpur lime citrus rootstock production in protecting the environment since significantly increased dry matter production (3A), height and stem diameter (3B). Evaluation of the mixture of urea and zeolite to avoid ammonia volatilization in pot with soil and Tanzaniagrass pasture are illustrate in Figure 4. The smallest losses by volatilization occurred at the proportions of the mixture of $25 \%$ of zeolite to urea and lead to a loss reduction from 33.5 to $7.6 \mathrm{~kg} / \mathrm{ha}$. Dry matter yield of silage corn as a function of $\mathrm{N}$ fertilizer level and zeolite ratio and type is illustrated in Figure 1. The highest 

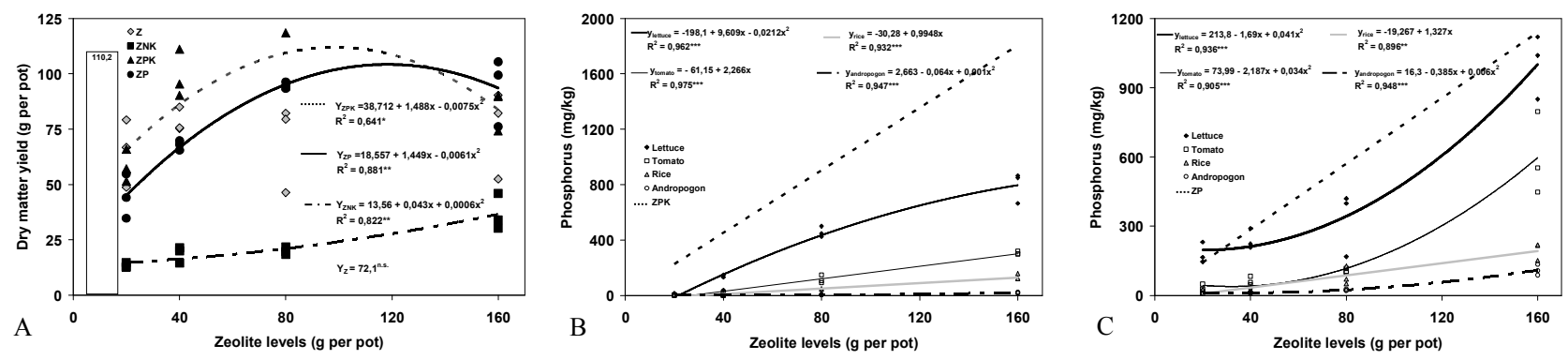

Figure 2. Dry matter yield of successive crops of lettuce, tomato, rice and Andropogon grass with $\mathbf{N}, \mathbf{P}$ and $\mathrm{K}$ enriched zeolite stilbite (A) and P availability of ZPK (B) and ZP (C) after each crop. Source: Bernardi et al. (2009b).
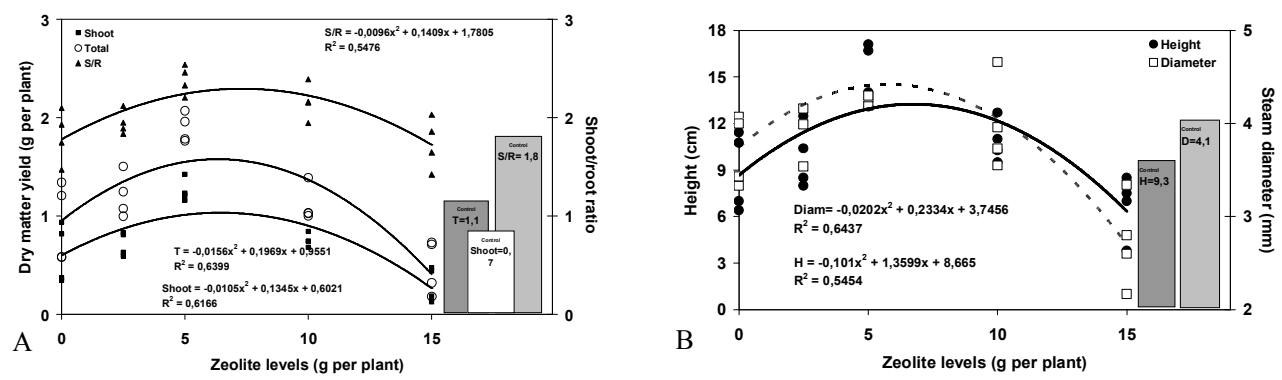

Figure 3. Dry matter yield, shoot/root ratio (A), plant height and stem diameter (B) of Rangpur lime rootstock according to level of zeolite stilbite. Source: Bernardi et al. (2008).
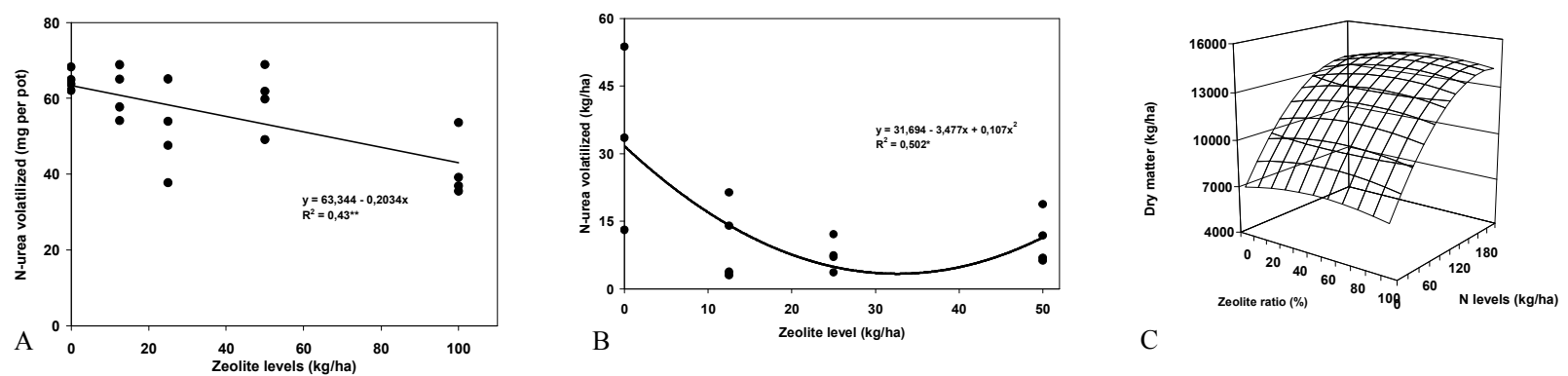

Figure 4. Losses of N-urea in pot (A) and Tanzania-grass pasture (B) experiments and silage corn dry matter yield (C) according to addition of zeolite stilbite. Source: Campana et al. (2009).
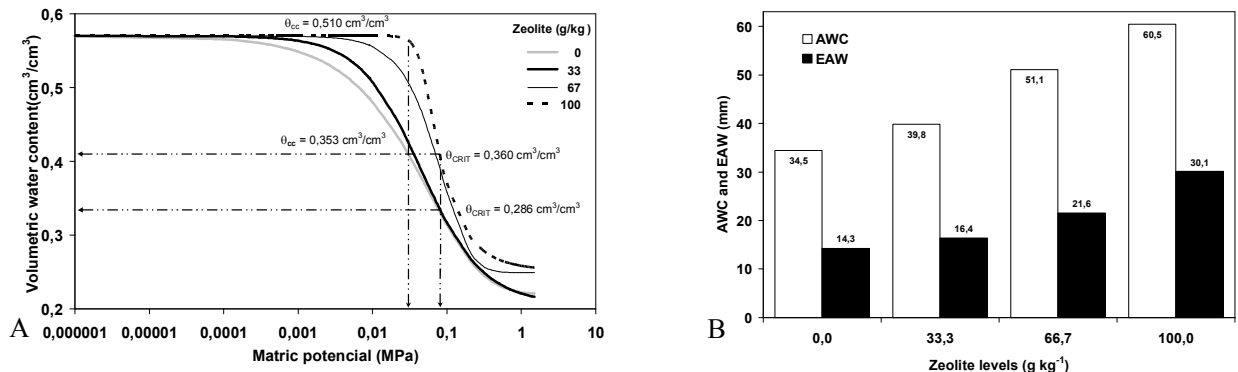

Figure 5. Water retention curve (A) available water capacity (AWC) and easily available water (EAW) (B) according to level of stilbite. Source: Bernardi et al. (2009a).

silage corn dry matter yield (14.5 kg/ha) was obtained with $183 \mathrm{~kg} / \mathrm{ha}$ of $\mathrm{N}$ plus $59.6 \%$ of concentrated zeolite (Figure 4C). The highest values of DM yields were approximately $48 \%$ higher than those obtained without nitrogen fertilizer, and only 5.5\% higher than DM yield obtained with $\mathrm{N}$ fertilizer but without zeolite. Zeolites are also an alternative to improve soil water retention when used as soil amendments. Results shown in Figure 5 indicate the change of water retention curve with zeolite amendment and on available water capacity increased 10,38 and $67 \%$ and easily available water increased 15,51 and $111 \%$ in relation to the control with the use of $33.3 ; 66.7$ and $100.0 \mathrm{~g} / \mathrm{kg}$ of zeolite. The present results indicate that despite their high-impurity content; applications of natural Brazilian zeolitic concentrates in agriculture present no major obstacle. And the addition of the zeolite - stilbite concentrate should increase the agronomic efficiency of fertilizer. 


\section{Conclusion}

The results indicated that concentrated zeolite enriched with N, P and K was an adequate slow-release source of nutrients to plants. Zeolite applied with urea improved $\mathrm{N}$ use efficiency and when applied with phosphate rock increased the $\mathrm{P}$ availability to plants and also increased water retention and the available water capacity of a sand soil when use as a soil conditioner.

\section{References}

Allen E, Ming D, Hossner L, Henninger D, Galindo C (1995) Growth and nutrient uptake of wheat in a clinoptilolite-phosphate rock substrate. Agronomy Journal 87, 1052-1059.

Barbarick KA, Lai TM, Eberl DD (1990) Exchange fertilizer (phosphate rock plus ammonium-zeolite) effects on sorghum-sudangrass. Soil Science Society of America Journal 54, 911-916.

Bernardi ACC, Mendonça FC, Werneck CG, Haim PG, Monte MBM (2009a) Disponibilidade de água e produção de arroz em função das doses de concentrado zeolítico. Irriga 14, 123-134.

Bernardi ACC, Monte, MBM, Paiva, PRP, Werneck CG, Haim PG, Souza-Barros, F (2009b) Produção de matéria seca e acúmulo de nutrientes após cultivos sucessivos com alface, tomate, arroz e capim andropogon em substrato com zeólita. Revista Brasileira de Ciência do Solo 33 (in press).

Bernardi ACC, Werneck CG, Haim PG, Rezende NGAM, Paiva PRP, Monte MBM (2008) Crescimento e nutrição mineral do porta-enxerto limoeiro 'Cravo' cultivado em substrato com zeólita enriquecida com NPK. Revista Brasileira de Fruticultura 30, 794-800.

Bouzo L, Lopez M, Villegas R (1994) Use of natural zeolites to increase yields in sugarcane crop minimizing environmental pollution. In ' $15^{\text {th }}$ World Congress of Soil Science, Acapulco, Mexico' pp. 695-701 (International Society of Soil Science: Acapulco).

Campana M, Bertolote LEM, Alves AC, Oliveira PPA, Bernardi ACC, Rochetti RC, Alves TC, Macedo FB, Morais JPG (2009) Volatilização de amônia em solo e pastagem de capim-tanzânia fertilizados com uréia e zeólita. Revista Brasileira de Zootecnia 39 (in press)

Crespo G (1989) Effect of zeolite on the efficiency of the $\mathrm{N}$ applied to Brachiaria decumbens in a red ferrallitic soil. Cuban Journal of Agricultural Science 23, 207-212.

He ZL, Calvert DV, Alva AK (2002) Clinoptilolite zeolite and cellulose amendments to reduce ammonia volatilization in a calcareous sandy soil. Plant Soil 247, 253-260.

Leggo PJ (2000) An investigation of plant growth in an organo-zeolitic substrate and its ecological significance. Plant and Soil 219, 135-146.

Ming DW, Dixon JB (1987) Quantitative determination of clinoptilolite in soils by a cation-exchange capacity method. Clays and Clay Mineralogy 35, 463-468.

Ming DW, Mumpton FA (1989) Zeolites in soils. In 'Minerals in soil environments' 2nd edn. (Eds JB Dixon, SB Weed) pp. 873-911. (Soil Science Society of America: Madison).

Monte MBM, Middea A, Paiva PRP, Bernardi ACC, Rezende NGAM, Baptista Filho M, Silva MG, Vargas H, Amorim HS, Souza-Barros F (2009) Nutrient release by a Brazilian sedimentary zeolite. Anais da Academia Brasileira de Ciências $\mathbf{8 1}$ (in press).

Mumpton FA (1999) La roca magica: Uses of natural previous zeolites in agriculture and industry. Proceedings of National Academy of Sciences of the United States of America 96, 3463-3470.

Pickering HW, Menzies NW, Hunter MN (2002) Zeolite/rock phosphate - a novel slow release phosphorus fertiliser for potted plant production. Scientia Horticulturae 94, 333-343.

Rezende NGAM, Angelica RS (1999) Sedimentary zeolites in Brazil. Mineralogica et Petrographica Acta 42, 71-82.

Van Straaten P (2006) Farming with rocks and minerals: challenges and opportunities. Anais da Academia Brasileira de Ciências 78, 731-747.

Xiubin H, Zhanbin H (2001) Zeolite application for enhancing water infiltration and retention in loess soil. Resources, Conservation and Recycling 34, 45-52. 